\title{
NIETZSCHE IN THE MAGISTERIAL TRADITION OF GERMAN CLASSICAL PHILOLOGY
}

\author{
BY JAMES WHITMAN*
}

Nietzsche spent ten years as an advanced student of classical philology and was a prodigious success; he spent the next ten years as a professor of classical philology and was a prodigious failure. Even casual readers of Nietzsche know the story of his meteoric early career in the dramatic terms in which it is usually told: how Nietzsche was called to the University of Basel in 1869, at the sensationally young age of twenty-four, and how he scandalized his colleagues in the discipline within three years by publishing the wild and unscholarly Birth of Tragedy, soon thereafter to abandon classical philology altogether and to be cast into disgrace, continuing to hold his professorship in name only.

Few Nietzsche scholars have resisted the temptation to exaggerate the drama of these events. The young Nietzsche, as we most often read about him, was a genius whom simple scholarship could not adequately nourish, a visionary who rapidly shook himself free of the grip of pedantry. ${ }^{1}$ Such is the standard account of Nietzsche's career, and it is badly distorted. For Nietzsche scholars have contented themselves with a careless caricature of the history of German classical philology. Certainly there was pedantry among Nietzsche's colleagues, but there was also a tradition that could appeal to Nietzsche's most visionary and self-proclamatory tendencies, a magisterial tradition that had arisen in the decades between 1790 and 1820 and flourished in the 1830s and 1840s. It is my purpose in this article to show that Nietzsche identified himself

* I would like to thank Professors Anthony Grafton, Samuel Jaffe, Arnaldo Momigliano, Donald R. Kelley, Hans Aarsleff, and John Atwell for their aid and advice in the writing and editing of this paper. All translations are my own, unless indicated otherwise.

${ }^{1}$ Misleading accounts, among the most widely available, include: R. Hayman, Nietzsche (London, 1980), 150; W. Kaufmann, Nietzsche (Princeton, 1974), 27; J. P. Stern, Nietzsche (Harmondsworth, 1978), 43; R. J. Hollingdale, Nietzsche (London, 1973), 213. Sounder accounts in E. Howald, Friedrich Nietzsche und die klassische Philologie (Gotha, 1920), 22, and esp. M. S. Silk and J. P. Stern, Nietzsche on Tragedy (Cambridge, 1981), 90ff. Other literature on Nietzsche and classical scholarship falls generally into two categories: assessments of Nietzsche's influence on later classicists (see Hugh LloydJones, "Nietzsche and the Study of the Ancient World," in O'Flaherty [ed.], Studies in Nietzsche and the Classical Tradition [Chapel Hill, 1976] and the literature cited there), and challenges to the originality of The Birth of Tragedy: see, e.g., M. L. Bauemer, "Das Moderne Phänomen des Dionysischen . . .," in Nietzsche Studien, VI, 1977, and esp. K. Gründer, "Jacob Bernays und der Streit um die Katharsis," in Epirrhosis. Festschrift f. Carl Schmitt (Berlin, 1968), 495-528. Most recently, see J. Figl, "Hermeneutische Voraussetzungen der philologischen Kritik,” in Nietzsche Studien, XIII, 1984. 
and his first book with this magisterial tradition. A subtler understanding both of Nietzsche and of the history of classical philology should result.

I. The Reception of The Birth of Tragedy-Silence. Only recently have M. S. Silk and J. P. Stern given us an accurate account of the events surrounding the publication of The Birth of Tragedy (BT). ${ }^{2}$ As I will show, Silk and Stern have left a great deal unexplored and unexplained, but they have done long-needed work in setting Nietzsche scholarship straight. For scholars continue to refer to the reception of $B T$ within the philological community of Nietzsche's time as "violent controversy." No phrase could be less apt. The professional response to Nietzsche's first book was in fact silence, and the task of historical interpretation is to explain that silence.

A brief review of the events is in order. Nietzsche published $B T$ in December of 1871 with a January 1872 imprint. No respectable journal reviewed it. None of the several professional journals of classical philology published any response. Nietzsche's friend and young contemporary Erwin Rohde, who had just received his first university appointment, attempted to place a review with a general-interest journal, the Litterarisches Centralblatt. Rohde's review was rejected, and Nietzsche lamented that the rejection had destroyed "the last possibility that a serious voice speak up for my book in a scholarly journal." ${ }^{4}$ The only philologist to publish a response was the young Ulrich von Wilamowitz-Moellendorff, later perhaps the leading classicist in the German world but at this time still without a university position. Wilamowitz, too, had trouble getting into print: he composed his long denunciatory essay in the hope that the Göttinger Anzeigen would accept it. He was told that "it wouldn't do for the Anzeigen" and was reduced to paying for a private printing in pamphlet form, which appeared only in June, seven months after $B T$ itself. $^{5}$ As for Nietzsche and Rohde, they had only in late May been able to place a favorable review with the Wagnerian newspaper the Norddeutsche Allgemeine Zeitung, which Nietzsche described to Rohde as a last resort: "The Norddeutsche is available to us-but doesn't it seem laughable to you? It does to me, at least." ${ }^{6}$ The Norddeutsche certainly seemed laughable to Wilamowitz. He poked fun at it in a second pamphlet, published in February of 1873, in response to an attack by Rohde: "The Dionysian organ is the Sunday Supplement of the Norddeutsche Allgemeine Zei-

${ }^{2}$ Silk and Stern, Nietzsche on Tragedy, 90ff.

${ }^{3}$ Hugh Lloyd-Jones, "Introduction" to Wilamowitz-Moellendorff, History of Classical Scholarship, trans. Harris (London, 1982), xii. Cf. K. Gründer in his introduction to Gründer (ed.), Der Streit um Nietzsches Geburt der Tragödie (Hildesheim, 1969), 7: "Die Fachgenossen schwiegen zunächst, dann erhob sich Streit. Jede Nietzsche-Darstellung verzeichnet diese Vorgänge als einen Skandal."

${ }^{4}$ Letter to Gersdorf, Feb. 4, 1872.

${ }^{5}$ Wilamowitz-Moellendorff, Erinnerungen (Leipzig, n.d.), 128-30.

${ }^{6}$ Letter to Rohde, mid-February, 1872. 
tung." 7 Thus the philological battle over $B T$ was fought out entirely in the published backwaters of the intellectual world.

Only two years after the book was published did a review finally appear in a philological journal. This review has been neglected by Nietzsche scholars, and I shall return to it in Section III below. As for the immediate response of the profession, Nietzsche said repeatedly that he considered it to be silence ${ }^{8}$ - he dismissed Wilamowitz. ${ }^{9}$ The idea that the profession met the book with "violent controversy" has always been based on the reactions of two philologists: Wilamowitz with his two pamphlets, and Herman Usener of Bonn. On close inspection, little can be made of the reactions of either man.

Wilamowitz has been referred to in this connection as "the guild." 10 But he was clearly an unrepresentative voice: he was a very junior member of the profession, having as yet no academic appointment; he found it impossible in any case, as just discussed, to publish his attack with a scholarly journal and so cannot be said to have broken the profession's publicly silent facade; and he had, according to his biographer, motives of personal animosity for attacking Nietzsche that the whole profession could not have shared. ${ }^{11}$

As for Hermann Usener, Nietzsche reported in two letters that Usener had declared him to be "wissenschaftlich tot" ("dead as a scholar"). These words have been described as "public censure." ${ }^{12}$ But Nietzsche's account of the incident hardly tallies with the description "public censure":

In Leipzig, there reigns one opinion about my book: according to this the excellent Usener, whom I so much respect, upon questioning from his students, has let slip [verrathen], "it is mere nonsense, of which nothing can be made: anybody who has written such a thing is dead as a scholar." It is as though I had committed a crime; there has been ten months of silence now, because everybody believes himself to be so far beyond my book, that there is not a word to be wasted on it. Thus Overbeck represents to me the situation in Leipzig. ${ }^{13}$

His students prodded Usener into making a pronouncement he never intended to make. The story is, if anything, strong evidence of Usener's intention to maintain silence as a senior member of the profession. Nietzsche understood the response of the profession to his book to be

${ }^{7}$ In Gründer (ed.), Streit um Nietzsches. . ., 114.

${ }^{8}$ See, e.g., letter to Rohde, March 16, 1872, and the account of Silk and Stern, Nietzsche on Tragedy, $90 \mathrm{ff}$.

${ }^{9}$ See, e.g., letter to Rohde, June 8,1872, in which Nietzsche suggests that Wilamowitz had been "used, stimulated, incited" by philologists who themselves maintained silence.

${ }^{10} \mathrm{~A}$. Hentschke and U. Muhlack, Einführung in die Geschichte der classischen Philologie (Darmstadt, 1972), 109.

${ }^{11}$ W. M. Calder, "Introduction" to Wilamowitz, In wieweit befriedigen die Schlüsse der erhaltenen griechischen Trauerspiele? (Leiden, 1974), 4 and note.

${ }^{12}$ Stern, Nietzsche, 35.

${ }^{13}$ Letter to Rohde, Oct. 25, 1872; cf. letter to Wagner, mid-November, 1872. 
silence; and with the doubtful exception of Wilamowitz, silence it was. Let us lay the "violent controversy" to rest.

But how, then, are we to explain to collective silence of the profession? Silence is not now, and was not then, the most common response to any book, however bad. The few scholars who have recognized the silence as silence have offered descriptions that do not amount to explanations: Ernst Howald called the profession's response "eisiges Schweigen"; ${ }^{14}$ Silk and Stern call it "silent disfavour." "Erwin Rohde later echoed Nietzsche's description - "it was as though I had committed a crime": Nietzsche was, said Rohde, "von seinen Fachgenossen, wie ein Verbrecher, mit scheuem Stillschweigen bestraft." 16 Perhaps one might say that Nietzsche was being given the silent treatment, meted out by student societies everywhere to transgressors of the social code, but what precisely was Nietzsche's offense? I shall now attempt to reconstruct it. Only by placing Nietzsche in the philological tradition to which he felt he belonged can we understand the silence that met his book. For the silence was the professional response not to Nietzsche's errors alone but to Nietzsche's errors within a distinctive scholarly tradition.

II. Nietzsche in the Magisterial Tradition. Perhaps the most useful unexploited source for placing Nietzsche in the history of classical philology is Wilamowitz's second denunciatory pamphlet. Wilamowitz had clearly been embarrassed by his public attack on Nietzsche, for he felt obliged to defend his first pamphlet at some length. In part the young Wilamowitz had committed a breach of scholarly etiquette in attacking a full professor. ${ }^{17}$ But there had been more than just cheekiness in his denunciation of Nietzsche, for Wilamowitz had left himself open to the charge that, in attacking Nietzsche, he was attacking the traditions of the profession itself.

Thus Wilamowitz denied that he objected to Nietzsche's project per se. Nietzsche's project, as Nietzsche described it in the opening sentence of $B T$, was to arrive "not only at a logical understanding, but at the unmediated certainty of Anschauung" 18 about the world of the Greeks; this project, as he told his teacher Friedrich Ritschl, Nietzsche considered "in the highest sense scientific." ${ }^{19}$ These were the same terms Wilamowitz

${ }^{14}$ Howald, Friedrich Nietzsche, 22.

${ }^{15}$ Silk and Stern, Nietzsche on Tragedy, 91.

${ }^{16}$ Quoted in Crusius, Erwin Rohde (Tübingen, 1902), 62.

${ }^{17}$ Wilamowitz wrote: "It is true, neither an ordinary nor an extraordinary professor, but a philologist without a name in the profession, took the liberty of showing the world ... that any Ph.D. could knock over [BT] ..." (in Gründer [ed.], Streit um Nietzsches. . , 114-15). Indeed, Nietzsche's lone philological reviewer (see below, Section III) had harsh words for the presumptuous Wilamowitz: H. Guhrauer, review of $B T$ in Jahrbücher f. Philologie u. Pädagogik, n.s., no. 109 (1874), 49.

${ }^{18}$ In Colli-Montinari, Gesamtausgabe (GAW) III(1), 21.

${ }^{19}$ Letter to Ritschl, April 6, 1872. 
used in his second pamphlet. The quest for Anschauung was, Wilamowitz said, nothing less than "the method of the science" itself, and he protested that he endorsed it-provided it was carried out only by scholars of the greatest eminence:

Have I taken up this struggle because I had perverted conceptions, crude errors, all in all philological sins to reproach [Nietzsche's theory] with? Or was it a tendency, as may perhaps be believed of me, to turn my efforts against $\mathrm{An}$ schauung of art as a whole, against the method of the science? No, there yawns an unbridgeable gulf here. To me, the highest idea is the unfolding of the world according to regular laws, full of life and reason. Gratefully do I look upon the great minds who, proceeding from level to level, have wrested out the world's secrets; with wonder do I seek to draw nearer the light of the eternally beautiful which art, in every different instance of its appearance [Erscheinung], expresses in its special way; and in the science which fills my life, I strive to follow the path of those who free my judgment, because I have willingly given myself into their charge. ${ }^{20}$

Wilamowitz feared that in attacking Nietzsche he would be perceived to be attacking a "great mind." Clearly Nietzsche resembled, at least in the eyes of his contemporaries, the philological master whom Wilamowitz describes. It is accordingly among the "great minds" that we must seek for the models Nietzsche set himself.

And Wilamowitz's "great minds" can readily be found in the firmament of German classical philology. There are innumerable passages in the philological literature of the 1830s, 1840s, and to a lesser extent 1850 s that closely resemble the passage of Wilamowitz just quoted. To represent the literature of the "great minds" in this earlier period in the history of the discipline, I have chosen a sample of the so-called "encyclopedias," general introductions to the study of Antiquity given by full professors at German universities. These "encyclopedic" lectures display not only the mastery of the professors that gave them but a whole ethic of mastery that pervaded classical philology in their time. Here, for example, is S. F. W. Hoffman, writing in the Introduction to his encyclopedic work published in 1835:

It has been my goal, faithful to the task before me, to stimulate independent thinking [eigenes Denken] by presenting the accepted wisdom, to stimulate independent investigation among already advanced students, in the broad field of the study of Antiquity, not in such a way that the student can be satisfied with the knowledge of single Erscheinungen from the life of the ancients, as they appear before our eyes in their written work and artwork, but in such a way that the student strive lovingly to investigate the Geist from which all those works proceed, and which, as it were, continues to preside over them, visible only to the spiritual eye. ${ }^{21}$

${ }^{20}$ In Gründer, Streit um Nietzsches..., 134.

${ }^{21}$ S. F. W. Hoffman, Die Altertumswissenschaft (Leipzig, 1835), v. 
We see here precisely the vocabulary of concepts Wilamowitz resorted to four decades later: the understanding of the pupil-teacher relationship in terms of the play of freedom and submission, the postulate that the remains of Antiquity are to be viewed singly as Erscheinungen of one greater Geist, the conviction that mastering the study of Antiquity is the business of cultivating "the spiritual eye." Hoffman was a "great Geist."

But we must turn to other encyclopedic literature for clear statements of what is only implicit in Hoffmann: the degree to which the doctrine of the discipline could center on the personal powers of the "great Geist." Here is Gottfried Bernhardy, in the Introduction to his important encyclopedia, ${ }^{22}$ published in 1832:

There is no lack of handbooks and rulebooks, either for the discipline as a whole or for its sub-disciplines; but their usefulness up until now has been uncertain and ambiguous. How should general norms bear fruit in so marvelous a field of knowledge, when knowledge establishes new ties with every subjectivity, and ends only with a hypothesis of many-sided form and fullness? If there is a way out of these contradictions, we must expect it from a master, who, at the end of his career, could resolve himself, with an illustrious candor of the heart to set down his student years, joys and sufferings, gains and errors, truths and wishes, as it were in an ennobled ana ... ${ }^{23}$

Bernhardy's emphasis on "Subjektivität" and on the biographical storehouse of wisdom that must inform scholarship were frequently echoed. Veneration of the master as scholar was not to be separated from the veneration of the master as man. The son of August Matthiä introduced his father's posthumous encyclopedia of 1835 in words largely borrowed from Bernhardy:

Well may the experience of half a century, which the blessed departed has set down in these pages with clear and simple words and with a candid heart, be welcome to many a man who, like the deceased, labors on this great structure [of philology] with free self-activity and from the deepest impulse of the soul. Of course, much remains here of the stamp of subjectivity, just as it will in all succeeding works of this kind, and new viewpoints will oppose themselves to the old, new assumptions will oppose themselves to old assumptions: who would offer his personal opinion as objective truth in this pathless, horizonless field? Nevertheless, conclusions of every kind, if they rise from the depths of the mind or from the golden treasury of a long life, are an abiding gain for the science. ${ }^{24}$

${ }^{22}$ Although forgotten, Bernhardy's Enzyklopädie was relied on by Nietzsche (see below n. 23) and by Matthiä (see below). It was in response to Bernhardy that Friedrich Ritschl composed his 1833 encyclopedic essay (see below).

${ }^{23}$ G. Bernhardy, Grundlinien zur Enzyklopädie (Halle, 1832), iv-v. Nietzsche repeatedly consulted this book while preparing his own encyclopedic lectures. See Oehler (ed.), Nietzsches Bibliothek (14te. Jahresgabe der Gesellschaft der Freunde des NietzscheArchivs, 1942).

${ }^{24}$ A. Matthiä, Enzyklopädie u. Methodologie d. Philologie (Leipzig, 1835), v-vi. 
Here, in the model of the "subjective" master philologist, was the very opposite of pedantry in the traditions of German classical philology.

What were these encyclopedic lectures? They were the forum in which the doctrines of German hermeneutics entered the daily practice of teaching. This everyday life of hermeneutic theory has not received notice in the growing literature on the nineteenth-century hermeneutics; scholars have discussed the theory of German classical philology and not the lecture-hall practice. ${ }^{25}$ It is beyond the compass of this article to reconstruct in its entirety the daily practice of classical hermeneutics. But it should be said that the sources of classical hermeneutics were in the work of F. A. Wolf and his students and colleagues, work that commanded broad public attention in Germany from the 1790s on. By the 1830s and 1840s the inspiration for the encyclopedic lectures of the many lesser philologists who gave them was first and foremost (though hardly exclusively) ${ }^{26}$ the work of August Boeckh (1785-1867), one of the greatest scholars of the first half of the nineteenth-century. Boeckh's encyclopedic lectures, given regularly for fifty-six years, from 1809-1865, were formed largely under the pressure of Boeckh's dislike for his University of Berlin colleague Hegel. ${ }^{27}$ Hegel asserted in the introduction to his own Enzyklopädie that all other encyclopedias were "Aggregate" ("mere compilations"). ${ }^{28}$ Boeckh understood this as a reference aimed at German classical philology, ${ }^{29}$ and he responded in two related ways: first, by paying careful attention to the systematic ordering of the various disciplines and subdisciplines of classical philology; and second, by insisting that the philologist give unity to his material by reliving it in his own mind. "Philology," he said, "does not renounce all individual ways of thinking [eigenes Denken]." The philologist reproduces his alien subject-matter in his own mind as "Eigenwerdendes" ("something becoming his own"),

${ }^{25}$ Standard surveys remain C. Bursian, Geschichte der classischen Philologie in Deutschland (2 vols.; München, 1883); J. Sandys, History of Classical Scholarship (3 vols.; Cambridge, 1908). See the English translation, Wilamowitz-Moellendorff, History of Classical Scholarship (London, 1982) with an introduction and notes by H. Lloyd-Jones. See also Righi, Breve Storia della philologia classica (Roma, 1962), and Hentschke and Muhlack, Einführung in die Geschichte der classischen Philologie. On the history of hermeneutic theory, see J. Wach, Das Verstehen (3 vols.; Tübingen, 1926) and H. Flashar (ed.), Philologie und Hermeneutik im Neunzehnten Jahrhundert (Göttingen, 1979). Very valuable on Nietzsche's philological generation is A. Bernardini and G. Righi, Il Concetto di filologia e di cultura classica nel pensiero moderno (Bari, 1947), 547-94.

${ }^{26}$ The most thorough survey of nineteenth-century hermeneutic theory is Wach, Das Verstehen. On Wolf, see e $\rightarrow$ A. Grafton, "Prolegomena to Friedrich August Wolf," in Journal of the Warburg and Courtauld Institutes, 44 (1981), 101-29.

${ }^{27}$ Cf. A. Momigliano, "Dall'epistolario di A. Boeckh," in Contributo alla storia degli studi classici (Roma, 1955), 384.

${ }^{28}$ G. W. F. Hegel, Enzyklopädie der Philos. Wissenschaften (Frankfurt a. M., 1969), I, 16, 61 .

${ }^{29}$ Cf. Wach, Das Verstehen, I, 175n. 
"wodurch," continued Boeckh, "eben auch der Aggregatzustand der Philologie aufgehoben wird." ${ }^{30}$ Here, in Boeckh's effort to steer German classical philology in the wake of Hegelianism, lies the ultimate origin of the vision of philological mastery invoked in Wilamowitz's 1873 pamphlet. Both the conviction that ancient art was the sum of Erscheinungen produced by a single Geist and the emphasis on the masterly, synthesizing sensibility of the individual philologist were aspects of a single Boeckhian assertion, that the Antiquity of the classicists was a totality. But the daily practice of Boeckhian hermeneutics deviated markedly from Boeckh's own conception. The idea that the individual philologist "re-lived" Antiquity encouraged a fascination, alien to Boeckh himself, with the scholarly biography of the philological master. It was this altered Boeckhianism, deeply tinged with Romanticism, whose daily practice constituted the magisterial tradition I have identified. This magisterial tradition continued, though with declining vigor, into Nietzsche's own student days. Nietzsche himself heard encyclopedic lectures in 1867. His notes include references ${ }^{31}$ to a number of works, among them Ludwig Lange's introduction to his lectures on Enzyklopädie und Methodologie der Philologie of 1855:

If one makes all the relationships between the various manifestations of the cultural life of the classical nations-relationships I have merely adumbratedthe chief object of scientific consideration; if one pursues them singly from a historical point of view, and sorts out from within them, as it were in one focus, the individual rays of the Greek and Roman spirit, one achieves the cultural history of Antiquity .... ${ }^{32}$

Finding the single focus was also the goal of philology as proposed in another article cited in Nietzsche's student notes on Enzyklopädie. This article is a particularly interesting source: it presents the task of the synthesizing master of classical philology as the task of an artist-the sort of man Nietzsche conceived himself to be: ${ }^{33}$

"Historian" includes ... not only those who bring material to the light of day by critical analysis, but also those who, as historians in the customary meaning of the name, reconstitute the recovered material by means of their constructive reproducing activity, to make a plastic apprehensible [anschaulichen] picture of the national life, presenting all essential aspects-a task more demanded of our

${ }^{30}$ Boeckh, Enzyklopädie u. Methodologie d. Philolog. Wissenschaften (Leipzig, 1877), 20. On Boeckh see Wach, Verstehen, I, 168ff. and the relevant essays in Flashar (ed.), Philolog. u. Hermeneutik im 19. Jht.

${ }^{31}$ Reproduced in Mette and Schlechta (eds.), Nietzsches Werke, IV, 3ff.

${ }^{32}$ Lange, "Die classische Philologie in ihrer Stellung zum Gesammtgebiete der Wissenschaften ...,", in his Kleine Schriften (Göttingen, 1887), I, $1 \mathrm{ff}$.

${ }^{33} \mathrm{Cf}$. letter to Rohde, March 29, 1871. 
times than accomplished. Virtuosity in the artistic intertwining of the branches of knowledge, making them a unity, is, in our age, the sign of personal genius. ${ }^{34}$

The appeal this sort of description of the philologist would have for the young Nietzsche will be clear. Scholars have been mistaken in asserting that Nietzsche's sense of artistic vocation would have been at odds with his profession as classicist, for artistry had its traditional place in German classical philology. Conversely, we must not assume that Nietzsche was being disingenuous when he claimed that his book was "in the highest sense scientific." 35

That phrase, "in the highest sense scientific," was one Nietzsche used in defending himself to his teacher, Friedrich Ritschl. He had good reason to hope for Ritschl's sympathy. For Ritschl was one of the last and most unreserved practitioners of the "subjective" magisterial philology of the 1830s. We possess two encyclopedic essays by Ritschl, one dating from 1833 , the other from $1857-58 .{ }^{36}$ I shall discuss the second of these, the one composed nearest in time to Nietzsche's own student years. This second essay is striking first of all because of its form: it is a collection of aphorisms, Nietzsche's own favored form. The essay falls squarely into the subjectivist strain embodied in Bernhardy and Matthiä, the presentation of "ennobled ana," of the "golden treasury of a long life." Ritschl's editor described it as elevated autobiography of the Bernhardian type:

... "On the Method of Philological Study" offers, it is true, only fragments and aphorisms and to that degree is only a weak substitute for the-as I clearly remember-general didactic discussion he had planned for the last volume of his opuscula, in which Ritschl wanted to set down his rich life experiences. ${ }^{37}$

We know from Ritschl's biographer that this "general didactic discussion" was to be a transcription of Ritschl's encyclopedic lectures. ${ }^{38} \mathrm{We}$ have the testimony of others that Ritschl's encyclopedia communicated as much as anything else the biography and personality of Ritschl. Here, for example, is Erwin Rohde, reviewing Otto Ribbeck's Ritschl:

One can hardly seriously ask, whether any other manner of presentation could be more fruitful than these lectures, in which the full personality of a richly

${ }^{34}$ (Anonymous), "Philologie und Sprachwissenschaft," in Preussische Jahrbücher, 7 (1861), 143.

${ }^{35}$ For the mistaken assumption that artistry and philology were perceived as incompatible, see, e.g., Hayman, Nietzsche, 140. Allan Megill speaks of the "antiscientific animus" of $B T$ without regard to Nietzsche's own belief that his book was "wissenschaftlich." Megill, Prophets of Extremity (Berkeley, 1985), 54. But Megill seems to me merely careless in his terminology in an otherwise sound interpretation. See below n. 47.

${ }^{36}$ Both in Ritschl, Opuscula Philologica (Leipzig, 1879), V, 1-18 and 19-37 respectively.

${ }^{37}$ Ritschl, Opusc. Philol., V, vii.

${ }^{38}$ Otto Ribbeck, Friedrich Wilhelm Ritschl (repr. Osnabrück, 1969), II, 279ff. 
and many-sidedly talented man was employed, even with that one-sidedness which formed a part of its strength. ${ }^{39}$

To Ribbeck, too, the aphorisms and fragments were "products of a rich experience." ${ }^{40}$ And Ritschl himself, while he still conceived the work as a direct transcription of his lectures, worried in a letter over what he knew would be a compendium of anecdotes and highly personal judgments.

Sharp and blunt things about people and affairs, living and dead, powerful and powerless, will certainly appear there, and I know, one is stirring up a hornet's nest. But what's the harm in the end? One is so glad to give vent to a hundred annoyances, one can let loose after school, state, and church, vanities, brutalities, stupidities and perversions, to one's heart's content, and the straying sheep should at least say, with Faust's student: one sees how and why. ${ }^{41}$

Such was the general encyclopedia of classical philology given by Nietzsche's principal teacher. The philological teaching tradition in which Nietzsche was trained required, and indeed celebrated, the display of a professor's powerful personality.

As for Nietzsche's own teaching activity, he repeatedly listed "encyclopedia," in his notes to himself during the period of his professorship, among the courses he intended to give. ${ }^{42}$ Nevertheless, he only lectured on encyclopedia once: during the Sommersemester of 1871, that is to say, while he was in the heat of composing $B T$. Nietzsche's encyclopedia, while marked by unusually elegant phrasing, falls recognizably into the tradition I have presented. Nietzsche offered his students traditional hermeneutic principles with an accent on the subjectivity of the scholar:

The faculty of historical understanding is nothing other than comprehension of particular facts under philosophical hypotheses. The loftiness of the hypotheses determines the value of the faculty of historical understanding. For a fact is infinite, never fully reproducible. There are only degrees of historical understanding.

One grasps at history and finds in it a collection of examples for one's knowledge [Erkenntnisse]. The more a man is an independent thinker, the more he will recognize [erkennen] in the past.

The philosophical hypothesis of classical philology is the classical character of Antiquity. We wish to comprehend the most lofty Erscheinung and grow to be one with it. The task is to live in and with Antiquity. ${ }^{43}$

These encyclopedic lectures can be linked directly to $B T$. For traditional

${ }^{39}$ Rohde, Kleine Schriften (Tübingen, 1901), II, 461.

${ }^{40}$ Ribbeck, Ritschl, II, 275.

${ }^{41}$ Ritschl, Opusc. Philol., V, 24.

${ }^{42}$ See, e.g., among the notes published in $G A W$, III(3), 240, 319; III(4), 245.

${ }^{43}$ In Nietzsche, Werke (Grossoktavausgabe, Leipzig, 1910), XVII, 329. 
though his pronouncements were, Nietzsche considered them to represent a revolutionary renovation of classical philology-precisely the kind of revolutionary renovation he hoped to spark with $B T$. As he described it in a letter to Rohde, his encyclopedia met with the shock that greets a tract of true reform: "I am now lecturing on 'Introduction and Encyclopedia' to the astonishment [Erstaunen] of my listeners, who have difficulty recognizing themselves in the picture I draw of the ideal philologist." ${ }^{44}$ This reformer's épater les philologues was precisely what Nietzsche and Rohde later hoped to achieve with Rohde's reviews of $B T$. Rohde, by giving documentary philological support to Nietzsche's thesis, was to throw the philologists into a "wholesome astonishment" (heilsames Erstaunen $){ }^{45}$ Rohde commended $B T$ "to the gentleman philologists, to beseech them to learn from the book that they, ceasing to be mere hairsplitters, can constitute the guardians of a nobler culture [Bildung] to which end they alone are able to possess, in the Greeks, the guiding model." ${ }^{46} B T$, too, was to form the "ideal philologist."

Of course the content of $B T$ was in many ways fresh and quite different from that of the magisterial literature of earlier generations. Nevertheless, $B T$ 's scholarly program was in the largest sense guided by older practices: the full title of the translated book was The Birth of Tragedy Out of the Spirit [Geist] of Music, and it represented a variant of the old postulate that Greek culture was to be viewed as the sum of "Erscheinungen" produced by the Greek "Geist." Nietzsche introduced only one fundamental modification into this old conception: he gave specific content, in the form of music, to the Geist that in earlier works remained exceedingly vaguely defined. In this respect Nietzsche's was a new view, but this new view arose out of an old claim to privileged insight, the claim of a "great Geist."

Nietzsche was, in short, fully able to consider himself a classical philologist without considering himself a pedant. Quite the contrary, he was able to consider himself a seer, an unfettered genius. Classical philology gave play to Nietzsche's least scholarly tendencies. But that is not to say that classical philologists accepted Nietzsche's pretensions. Wilamowitz recognized that Nietzsche claimed to belong to the great tradition, but he refused to acknowledge Nietzsche as a "great Geist." Other philologists refused even to take notice of the publication of his book. I shall now return to the reception of $B T$, and attempt to account for their silence.

III. The Contested Magisterial Tradition. The magisterial tradition was not unchallenged within German classical philology. Also present in the philological practice of Nietzsche's day was what is best called

${ }^{44}$ Letter to Rohde, June 7, 1871.

${ }^{45}$ Letter to Rohde, June 18, 1872.

${ }^{46}$ Quoted in Crusius, Rohde, 56. 
"positivism," a tradition that emphasized the recovery and assessment of facts about Antiquity, of what were called Realien. The coexistence of these two traditions was visible on library shelves: alongside the encyclopedias of Bernhardy and Matthiä sat Pauly's Real-Enzyklopädie, which began appearing in 1837. Pauly arranged his material alphabetically, where Bernhardy and Boeckh arranged theirs conceptually. In the breast of contemporary classical philology dwelt both esprit de systeme and esprit systématique.

It was an uneasy coexistence. Philologists greatly distrusted Materialismus ${ }^{47}$ and accommodated themselves only hesitantly to the positivism that seemed linked to the materialist point of view. The collection of facts did not seem to require the special insight, the scholarly genius, German classicists valued. Here is Lucian Müller, a biographer of Friedrich Ritschl, writing in 1878. Müller associated positivism with scholarly travaux d'équipe:

... Materialism is and must be the enemy of all philological and historical investigation.

I mentioned before collaboration among philologists.

It is, from time to time, bemoaned that philologists so rarely join together in common labor. But I believe that, on this account, they deserve more praise than blame. In order to establish this, I must first explain what I mean by common labor. I do not refer to that more mechanical form of collaboration in which, as occasionally happens, older, renowned scholars associate themselves with younger, less-well-known men, principally for the collection and classification of materials, for, so to speak, the coarser work, while reserving to themselves the lion's share of spiritual creation [des geistigen Schaffens] and even more of literary fame. It has to do rather with the question, in how far it is advisable that two philologists of equal qualification and rank engage in united labor on one and the same object of scholarly study.

Now it seems to me that very weighty considerations stand against such a collaboration.... [I]t seems quite impossible ... when it comes to the highest and noblest task of formal philology: the unified, artistically rounded, restitution of works of literature; impossible, even if the two philologists in question were entirely equal in talent and mutual toleration. For ... the critic often considers such subtle details of knowledge and judgment, that it is difficult to make them even comprehensible to someone else-let alone that the task could be accom-

${ }^{47}$ Cf. J. Whitman, "From Philology to Anthropology . . .," in History of Anthropology, ed. G. Stocking (1984), II, 214-29; cf. also L. Gossman, Orpheus Philologus (Philadelphia, 1983). For Nietzsche's place in the materialistic controversy, Allan Megill's observations on the "antiscientific animus" of $B T$ (cf. above n. 35) are valuable but terminologically misleading. Nietzsche was, after all, convinced of the "scientific" character of his work. To characterize the young Nietzsche accurately, one should speak of his "antimaterialistic" or "antipositivistic" animus. 
plished except through the unified efforts of one Geist, conscious with perfect precision of its means and ends. ${ }^{48}$

Here the conflict of philological worlds stood clearly on display. As long as at least some philologists continued to reverence the unique authority of "older, renowned scholars," and to demand "unified, artistically rounded" interpretation, the study of Realien would be viewed patronizingly, if not contemptuously.

For its part, the magisterial tradition also stimulated resentment. Some of this resentment focused on Friedrich Ritschl, who left the University of Bonn in 1865 in the wake of a widely publicized feud with his colleague Otto Jahn. Opposition to Ritschl at Bonn grew partly out of the sense that Realien had too little place in his teaching. The historian Heinrich von Sybel expressed his dissatisfaction with Ritschl:

... Knowledge of the facts about Antiquity [reale Kenntnis des Altertums], of its history, its circumstances, its literature, is at no other German university in so sorry a state as here. No semester goes by in which a philologist does not receive his degree magna cum laude, who knows nothing about the existence of Thucydides, confuses Appian and Ammianus, makes conjectures about Livy, without however knowing the content of the relevant chapter. ${ }^{49}$

Such hostility was rarely voiced, but it was real. The magisterial tradition could be an irritation in the age of positivism.

The magisterial tradition could also be an embarrassment. Later, in the 1880 s, serious hermeneutics, stripped of its emphasis on the personality of the philologist, enjoyed an unabashed revival, championed first and foremost by Hermann Usener. ${ }^{50}$ But in the 1870 s, when $B T$ was published, even the most serious hermeneutics, that of Boeckh, went uncelebrated. Boeckh's encyclopedic lectures were published posthumously in 1877. Remarkably-for Boeckh's Enzyklopädie was a principal work of a very great scholar-philologists met the publication with silence. In other circles the appearance of the book was treated as a major event: one journal published a forty-page review, and within two years there was a Russian translation and a full-length exegetical book, ${ }^{51}$

${ }^{48}$ L. Müller, Gedanken über das Studium der classischen Philologie (Berlin, 1878), 81-82; for hostility to travaux d'équipe in the 1850s, cf. A. Heuss, "Niebuhr und Mommsen," in Antike und Abendland, 14 (1968), 7-8.

${ }^{49}$ Quoted in Hübinger, Das Historische Seminar d. Rhenischen Friedrich-WilhelmsUniversität zu Bonn (Bonn, 1963), 164. Cf. id., "Heinrich von Sybel und der Bonner Philologenkrieg," in Hist. Jahrb., 83 (1964), 162ff. The reference to conjectures reminds us that Ritschl was a student of G. Hermann: in positivism, Boeckhianer and Hermannianer had a common enemy.

${ }^{50}$ Cf. A. Momigliano (ed.), Aspetti di Hermann Usener filologo della religione (Pisa, 1983).

${ }^{51} \mathrm{H}$. Steinthal, rev. of Boeckh, Enzyklopädie, in Zeitschrift für Völkerpsychologie und Sprachwissenschaft, IX, 5ff; X, 238ff.; Heerdegen, Idee der Philologie (Erlangen, 1879). 
but not a single philological journal published any notice. Only one philologist published a response, and it was an odd one: it appeared in the Jenaer Literaturzeitung and offered a strangely assorted combination of carping at the editing of the book, grand revision of the philosophical underpinnings of Boeckh's scheme, and denials of the necessity of publishing at all. ${ }^{52}$ Bursian's Jahresbericht reported on Boeckh's Enzyklopädie, as on most of the year's literature in classics, but restricted itself to a précis of Boeckh's system, while denying the scholarly importance of the book outright: "A critique of the content of Boeckh's lectures would be out of place here, since they already belong to the history of our discipline and cannot be treated as a new endeavour." ${ }^{53}$ No doubt Boeckh's Enzyklopädie did "belong to the history of the discipline" in a sense; but he continued to give his lectures until 1865 , and he was a scholar of indisputable significance. It was at best ungracious to date Boeckh to the discipline's early years in this way; it was, however, a sign of the times. The Boeckhian tradition lived on in the beliefs and practices of many philologists, as is clear in Wilamowitz's manifest loyalty to it: Wilamowitz denied Nietzsche the title of "great mind" with such ferocity because he believed with such fervor in the importance of great minds. ${ }^{54}$ But philologists without the independent temperament and powerful mind of Wilamowitz were reluctant to call attention to what might too easily have seemed unscientific tendencies in the discipline. Hence the silence that greeted Boeckh's Enzyklopädie, as five years earlier it had greeted the infinitely less scholarly $B T$.

For, I submit, the silence was the same. $B T$ was ignored rather than denounced because it clearly represented, or perhaps perverted, a tradition which was alive but something of an embarrassment to classicists. Were the tradition not alive, Nietzsche might have stirred up a "violent controversy." As it was, he brought down upon himself the same neglect that was the lot of Boeckh.

Two years after $B T$ appeared, the silence was broken: a philological review appeared. But two years late was very late by the standards of

${ }^{52}$ Martin Hertz, rev. of Boeckh, Enzyklopädie, in Jenaer Literaturzeitung, 22 (1878), $334 \mathrm{ff}$.

${ }^{53}$ C. Bursian, rev. of Boeckh, Enzyklopädie, in Bursian (ed.), Jahresbericht, 11 (1877), 35.

${ }^{54}$ On Wilamowitz see Calder, "Introduction" to Wilamowitz, In wieweit befriedigen die Schlüsse der erhaltenen griechischen Trauerspiele?, Lloyd-Jones, "Introduction" to Wilamowitz, History of Classical Scholarship, and A. Momigliano, "Premesse per una discussione su Wilamowitz," in his Sesto Contributo alla storia degli studi classici e del mondo antico (Rome, 1980), I, 337-49. Wilamowitz's commitment to the hermeneutic tradition should be viewed in light of his being a student (though a disaffected one) of Usener as well as of Jacob Bernays, whose interpretation of Aristotle's catharsis prefigured $B T$ (see Gründer, "Jacob Bernays und der Streit ...," in Epirrhosis. Festschrift f. C. $S c h m i t t)$ and itself reflected a profound struggle to reconcile scholarly tradition and materialism. 
the day. Nietzsche, who had already begun to drift far away from philology, took, to my knowledge, no notice of the review; neither, indeed, have Nietzsche scholars since considered it. ${ }^{55}$ Participants in the affair continued to view the reception of $B T$ as silence. ${ }^{56}$ The forgotten review is a fascinating source nevertheless, for it testifies to the difficulty philologists had in judging Nietzche's work against the standards of two separate and conflicting disciplinary traditions: the magisterial and the positivist.

The reviewer, Heinrich Guhrauer, represented, on the whole, the Realien. Guhrauer was a specialist in ancient music, and he was harsh with Nietzsche for his errors of fact and logic. But he found it impossible, despite his distaste for Nietzsche's loose scholarly practices, not to praise Nietzsche's Anschauungen:

The fundamental thought of the rather wide-ranging section on the death of tragedy, namely that the works of Euripides are, by contrast with those of Aeschylus and Sophocles, "sicklied o'er with the pale cast of thought," is in itself nothing new; but it is illuminated from the point of view of Nietzsche's Anschauungen, and it cannot be denied that one finds precisely in this section many truly ingenious verdicts, many dazzling turns of phrase. It is just that one must not, once again, be too particular about the historical details; one must understand the names "Euripides" and "Socrates"- - even if Nietzsche cannot restrain himself from weaving in all sorts of little anecdotes about both menmerely as types of the cultural tendencies [Geistesrichtungen] they represent, just as earlier in the book "Apollo" and "Dionysus" are to be taken as types, names not used in the exact philological sense. With this concession, which Wilamowitz is not inclined to make, one avoids the necessity of reproaching Nietzsche for all sorts of anachronisms and ignorances; of course, at the same time, one has renounced all hope of extracting any gain for exact philology from Nietzsche's book. ${ }^{57}$

In this provocative mix of esteem and repudiation there spoke the authentic voice of German classical philology, with its double methodological loyalty. On the one hand Nietzsche had "illuminated" a scholarly question; on the other hand he offered no hope of any gain for "exact philology." On the one hand Guhrauer valued Nietszche's Anschauungen; on the other he recognized Nietzsche's "anachronisms and ignorances." Friedrich Ritschl had produced another student whose "reale Kenntnis des Altertums" was doubtful. In the end, Guhrauer dismissed Nietzsche in the name of "exact philology": "The author of $B T$ is incontestably an

ss The review, by H. Guhrauer, in the Jahrbücher f. Philologie und Pädagogik, n.s., no. 109 (1874), 49ff., is listed in K. Schlechta, International Nietzsche Bibliography, but does not seem to have been discussed by any scholar.

${ }^{56}$ Cf. $n .16$ above.

${ }^{57}$ Guhrauer, review of Nietzsche, Geburt der Tragödie, in Jahrbücher f. Philologie u. Pädagogik, n.s., no. 109 (1874), 62. 
ingenious man," Guhrauer wrote at the end of his review, "but in this book he does not show himself a philologist." ${ }^{8}$ And yet any philologist willing to be "not too particular about historical details" would find "truly ingenious verdicts, dazzling turns of phrase."

Nietzsche had made an illegitimate claim to magisterial scholarly authority, but it was a type of authority to which the air of legitimacy clung nevertheless. If Nietzsche was a bad scholar, he was bad within a distinctive tradition, and a tradition with a peculiar place in the history of classical philology in Nietzsche's time. Therefore the history of classical philology is not complete without the bad scholar Nietzsche, just as Nietzsche is unnecessarily misunderstood outside the history of classical philology.

The University of Chicago. 